\title{
Estimating Solubility of Parathion in Organic Solvents
}

\author{
Illker Polatoğlu, Yılmaz Yürekli, Suat Bahar Baştürk \\ ${ }^{1,2}$ Celal Bayar University, Faculty of Engineering, Bioengineering Department, Manisa. \\ ${ }^{3}$ Celal Bayar University, Faculty of Engineering, Material Engineering Department, Manisa. \\ e-mail: ilker.polatoglu@cbu.edu.tr; yılmazyurekli@cbu.edu.tr; bahar.basturk@cbu.edu.tr
}

SubmissionDate:03.08.2015; Acceptance Date:12.10.2015

\begin{tabular}{cl} 
& Abstract \\
\cline { 2 - 3 } $\begin{array}{c}\text { Keywords } \\
\text { Parathion, Solubility, } \\
\text { Organic Solvent. }\end{array}$ & $\begin{array}{l}\text { As the organophosphorus pesticides (OP) is slightly soluble in water, addition of organic solvents is } \\
\text { needed for residue analysis. Solubility is a significant parameter for the selection of organic solvents. In } \\
\text { this study solubility of parathion (as a model OP) in water organic solvent (methanol, ethanol, isopropyl } \\
\text { alcohol, acetone and acetonitrile) mixtures were estimated. Thermodynamic solid liquid equilibrium } \\
\text { model is proposed to describe the solubility. The model gave satisfactory results and could be used to } \\
\text { estimate the solubility of otherOP. }\end{array}$ \\
\hline
\end{tabular}

(C) Afyon Kocatepe Üniversitesi

\section{Paratiyon'un Organik Çözücülerdeki Çözünürlüğünün Hesaplanması}

\begin{abstract}
Özet
Anahtar Kelimeler

Paratiyon, Çözünürlük,

Organik Çözücüler.

Organofosfatı pestisitlerin (OP) sudaki çözünürlükleri sınırlı olduğundan, pestisit kalıntı analizi için ortama organik solvent ilavesi gerekmektedir. Çözünürlük organik çözeltilerin seçiminde önemli bir parametredir. Bu aşamada paratiyon'un (model bir OP olarak) çözünürlüğü, su ve organik çözücü (etanol, metanol, izopropil alkol, aseton ve asetonitril) karışımlarında hesaplanmıştır. Termodinamik katı sıvı denge modeli çözünürlüğün ifade edilmesi için önerilmiştir. Model güvenilir sonuçlar vermiştir ve diğer OP'ın çözünürlüklerinin hesaplanması için kullanılabilir.
\end{abstract}

(C) Afyon Kocatepe Üniversitesi

\section{Introduction}

The use of pesticides becomes inevitable to protect the agricultural product from pest and herb. However their usage comes out some problems due to their toxicity. Especially organophosphorus oneis harmful for human health and ecological balance. The use of pesticides in agriculture is extensive(Walz and Schwack 2007). Thusthere is an increasing demand to develop fast methods for residue analysis.

As compared to the traditional techniques (spectrophotometric and chromatographic) applied for pesticide detection, biochemical sensors could be a reliable and promising alternative due to their lots of advantages such as simplicity, ease of use, and high sensitivity and selectivity (Rekha et al. 2000; Solna et al. 2005; Lee et al. 2002; Ramırez et al. 2008). These methods rely on the fact that organophosphorus pesticides (OP) inhibit the biological activity of particular enzymes.

Pesticide detection is generally performed in aqueous solutions (Turdean and Turdean 2008). Water solubility of most pesticides is very low with respect to organic solvents. Necessary amount of pesticide has to be dissolved for residue analysis. On the other hand theirresidues have to be extracted by using the solvents from food. However enzymes show limited tolerance for the solvents. Therefore their effect on enzyme activity has to be considered [1]. Mainly two phenomena can cause the change in enzyme activity: (a) distortion of enzymes or (b) probable inhibitors through specific interactions with enzymes, which could lead to 
changes in the reaction kinetics and substrate specificity (Pazhang et al. 2006).

All taken together, an appropriate solvent has to be chosen by taking into consideration the inhibition rate and solubility of OPin selected organic solvent. There are limited studies about the experimental solubility data for the pesticide in water-organic solvent containing media. Therefore the use of thermodynamic model gains importance to describe the experimental solubility data. This study aims to estimate the solubility of OP (parathion as a model compound) in different organic solvents(ethanol, methanol, isopropyl alcohol, acetone and acetonitrile) containing media.

\section{Thermodynamic Modeling Framework}

\subsection{Solubility of solute (OP)in water-organic} solvent mixture

The mole fraction of OP in theliquid phase (OP solubility) can be calculated usingthe following expression(Sandler, 2006):

$\ln x_{1}=-\ln \gamma_{1}-\left[\frac{\Delta f u s \underline{H}\left(T_{m}\right)}{R T}\left(1-\frac{T}{T_{m}}\right)\right]_{(1)}$

where

$x_{1}$ : Solubility of OP in organic solvent-water mixture

$\gamma_{1}$ : Activity coefficient of OP in water-organic solvent mixture

$\Delta$ fus $\underline{H}\left(T_{m}\right)$ : Enthalpy of fusion for OP (j/mol)

$R$ : Universal gas constant (J/molK): 8.314

$T:$ Temperature (K)

$T_{m}$ : Melting temperature of $\mathrm{OP}(\mathrm{K})$

Thus, to calculatethe OP solubility, physical properties of OP (given in Table 1 for parathion) and athermodynamic model to calculate $\gamma_{1}$ are required.

If the liquid mixture is ideal, so that $\gamma_{1}=1$. For nonideal solutions, $\gamma_{1}$ must be estimated from either experimental data or a liquid solution model, for example, UNIFAC. Alternatively, the regular- solution theory can estimate the activity coefficient.

\subsection{Estimation of activity coefficient for $O P$ in organic solvent-water mixture}

Regular solution theory is functionally equivalent to the van Laar theory(Sandler, 2006):

$R T \ln \gamma_{1}=\underline{V}_{1}(\delta-\bar{\delta})^{2}$

$\bar{\delta}=\sum_{j} \Theta_{j} \delta_{j}$

$\Theta j=\frac{x_{j} \underline{V}_{j}}{\sum_{k} x_{k} \underline{V}_{k}}$

Where

$\delta$ : Solubility parameter of OP $\left(\mathrm{cal} / \mathrm{cm}^{3}\right)^{1 / 2}$

$\bar{\delta}$ : Solubility parameter of water-organic solvent mixture $\left(\mathrm{cal} / \mathrm{cm}^{3}\right)^{1 / 2}$

$\delta_{j}$ : Solubility parameter of solvent (water and organic solvent)

$\Theta_{j}$ : Volume fraction ofsolvent (water and organic solvent)

$x_{j}, x_{k}$ : Mole fraction of solvent (water and organic solvent)

$\underline{V}_{j}, \underline{V}_{k}$ :Molar volume of solvent (water and organic solvent $)\left(\mathrm{cm}^{3} / \mathrm{mol}\right)$

$V_{1}$ : Molar volume of OP $\left(\mathrm{cm}^{3} / \mathrm{mol}\right)$

$\underline{V}_{1}=\frac{M_{w(O P)}}{\rho_{(O P)}}, \underline{V}_{j, k}=\frac{M_{w(\text { solven } t)}}{\rho_{(\text {solvent })}}$

$M_{w}:$ Molecular weight $(\mathrm{g} / \mathrm{mol})$

$\rho$ :Density $\left(\mathrm{g} / \mathrm{cm}^{3}\right)$

Solubility parameters for water and organic solvents were also calculated and represented in Table 2. Solubility parameter of OP should be estimated in order to calculate the activity coefficient of OP. 


\subsection{Estimation of solubility parameter for $O P$}

$\delta=\left(\frac{\Delta v a p \underline{U}}{\underline{V}_{1}}\right)^{1 / 2}=\left(\frac{\Delta v a p \underline{H}-R T}{\underline{V}_{1}}\right)^{1 / 2}$

where

$\delta$ : Solubility parameter of OP $\left(\mathrm{cal} / \mathrm{cm}^{3}\right)^{1 / 2}$

$\Delta v a p \underline{U}$ : Vaporization internal energy of $\mathrm{OP}$ $(\mathrm{J} / \mathrm{mol})$

To compute the solubility parameter for OP it is necessary to calculate the vaporization enthalpy of OP $(\Delta v a p \underline{H})$ by using the Clausius-Clapeyron Equation [8]:

$\frac{\ln P^{v a p}\left(T_{2}\right)}{\ln P^{v a p}\left(T_{1}\right)}=-\frac{\Delta v a p}{R}\left(\frac{1}{T_{2}}-\frac{1}{T_{1}}\right)$

where

$\Delta v a p \underline{H}$ : Vaporization enthalpy of OP $(\mathrm{J} / \mathrm{mol})$

$P^{\text {vap }}\left(T_{1}\right)$ : Vapor pressure of OP at temperature $T_{1}$ (Pa)

$P^{v a p}\left(T_{2}\right)$ : Vapor pressure of OP at temperature $T_{2}$ $(\mathrm{Pa})$

Finally it is necessary to estimate the enthalpy of fusion for OP ( $\Delta$ fus $\underline{H}\left(T_{m}\right)$ ) in order to calculate solubility of solute (OP) in water-organic solvent mixture.

\subsection{Estimation of enthalpy of fusion}

Solubility of OP (parathion as a model compound) in water at different temperatures given in Table 3 were used to calculate $\Delta$ fus $\underline{H}\left(T_{m}\right)$ (Sandler, 2006) $\ln \left(\frac{S_{1}}{S_{2}}\right)=-\frac{\Delta f u s \underline{H}}{R}\left(\frac{T_{2}-T_{1}}{T_{1} T_{2}}\right)$

where

$S_{1}$ : Solubility of OP in water at temperature $\mathrm{T}_{1}$ (mg/L)

$S_{2}$ : Solubility of OP in water at temperature

$\mathrm{T}_{2}(\mathrm{mg} / \mathrm{L})$

\section{Results and Discussions}

Solubility of parathion in different water organic solvents mixtures were predicted by using the thermodynamic solid-liquid equilibrium (SLE) expression (eq 1)(Leontarakis et al. 2005; Spiliotis and Tassios 2000). Ethanol, methanol, isopropyl alcohol, acetone and acetonitrile were selected as organic solvents. Four steps were applied for thermodynamic modeling framework. To estimate the parathion solubility, physical properties of parathion, Enthalpy of fusion and activity coefficient of parathion are needed. Table 1 gives the physical properties of parathion.

As a first step vaporization enthalpy of parathion $(\Delta v a p \underline{H})$ was calculated as $120.823 \mathrm{Kj} / \mathrm{mol}$ by using the vapor pressure of parathion at the temperature of 25 and $30{ }^{\circ} \mathrm{C}$ (eq 7). Then solubility parameter of parathion $(\delta)$ was found as 11.062 $\left(\mathrm{cal} / \mathrm{cm}^{3}\right)^{1 / 2}$ from eq 6 .

Table 1. Physical properties and solubility parameters of parathion(Mackay et al. 2006).

\begin{tabular}{cccccccc}
\hline OP & $\mathbf{M}_{\mathrm{w}}$ & $\rho\left(\mathrm{g} / \mathrm{cm}^{3}\right)$ & $\underline{\mathrm{V}}_{1}\left(\mathrm{~cm}^{3} / \mathrm{mol}\right)$ & $\mathrm{P}^{\text {vap }}(\mathrm{Pa})^{*}$ & $\mathrm{P}^{\mathrm{vap}}(\mathrm{Pa})^{\#}$ & $\Delta \underline{\text { Hvap}}(\mathrm{J} / \mathrm{mol})$ & $\delta\left(\mathrm{cal} / \mathrm{cm}^{3}\right)^{1 / 2}$ \\
\hline Parathion & 291.261 & 1.260 & 231,160 & $5.04 * 10^{-3}$ & $1.23 * 10^{-2}$ & 120823 & 11.062 \\
\hline
\end{tabular}

*:at $293.25 \mathrm{~K},{ }^{\#}:$ at $298.15 \mathrm{~K}$

Solubility parametersof water-organic solvent mixtures $(\bar{\delta})$ are needed to estimate the activity coefficient of parathion as second step. This parameters depicted in Table 2 were obtained by using the vaporization enthalpy of solvents and applying the eq 3 , eq 4 and eq 5 . To express the solubility of parathion as a mole fraction $\left(x_{1}\right)$ enthalpy of fusion for parathion $\left(\Delta f u s \underline{H}\left(T_{m}\right)\right)$ is required. 
Table 2. Physical properties and solubility parameters of water and organic solvents(Mackay et al. 2006).

\begin{tabular}{cccccc}
\hline Solvent & $\mathbf{M}_{\mathrm{w}}$ & $\boldsymbol{\rho}\left(\mathrm{g} / \mathrm{cm}^{3}\right)$ & $\underline{\mathbf{V}}_{\mathrm{j}, \mathrm{k}}\left(\mathbf{c m}^{3} / \mathbf{m o l}\right)$ & $\Delta \underline{\text { Hvap}}(\mathrm{J} / \mathbf{m o l})$ & $\delta_{j}\left(\mathbf{c a l} / \mathbf{c m}^{3}\right)^{1 / 2}$ \\
\hline Water & 18.020 & 0.997 & 18.069 & 43990 & 23.433 \\
Ethanol & 46.070 & 0.789 & 58.390 & 38560 & 12.153 \\
Methanol & 32.040 & 0.792 & 40.465 & 35278 & 13.919 \\
Isopropyl-alcohol & 60.100 & 0.786 & 76.463 & 44000 & 11.392 \\
Acetone & 58.080 & 0.790 & 73.519 & 31300 & 9.680 \\
Acetonitrile & 41.050 & 0.777 & 52.831 & 33225 & 11.794
\end{tabular}

Solubility of parathion in water at the temperature of 20 and $30{ }^{\circ} \mathrm{C}$ given in Table 3 were used to calculate $\Delta f u s \underline{H}\left(T_{m}\right)$ as third step. This parameter was found as $12.122 \mathrm{Kj} / \mathrm{mol}$ from eq 8 . Finally solubility of parathion in five different water organic solvent mixtures could be obtained from eq 1 as last step.

Table 3. Solubility of parathion in water at different temperatures and fusion enthalpy of parathion*

\begin{tabular}{cccccccc}
\hline OP & $\mathrm{T}_{\mathrm{m}}$ & $\mathrm{T}_{\mathbf{1}}$ & $\mathrm{T}_{\mathbf{2}}$ & $\mathrm{S}_{\mathbf{1}}(\mathbf{m g} / \mathrm{L})$ & $\mathbf{S}_{\mathbf{2}}(\mathrm{mg} / \mathrm{L})$ & $\mathbf{R}(\mathrm{J} / \mathrm{molK})$ & $\Delta \underline{\text { Hfus}(\mathrm{J} / \mathrm{mol})}$ \\
\hline Parathion & 279.250 & 293.150 & 303.150 & 12.900 & 15.200 & 8.314 & 12122 \\
\hline
\end{tabular}

*:(Mackay et al. 2006).

According to the results, solubility values of parathion are different for each solventas depicted in Figure 1.As expected, its solubility increases with increasing the volume of organic solvents. Solubility of parathionin organic solvents for all volume fractions was found as following order; acetone $>$ isopropyl alcohol $>$ acetonitrile $>$ ethanol $>$ methanol (shown also in inset of Figure 1). This result is accordance with the solubility parameters of organic solvents (inverse relationship). The solubility parameter is a numerical value that indicates the relative solvency behavior of a specific solvent(Burke, 1984).Soluble amount of parathion increases when the organic solvent with the lower value of the solubility parameter was used. Parathion is less soluble in methanol and most soluble in acetone. Therefore acetone could be selected to dissolve the parathion for residue

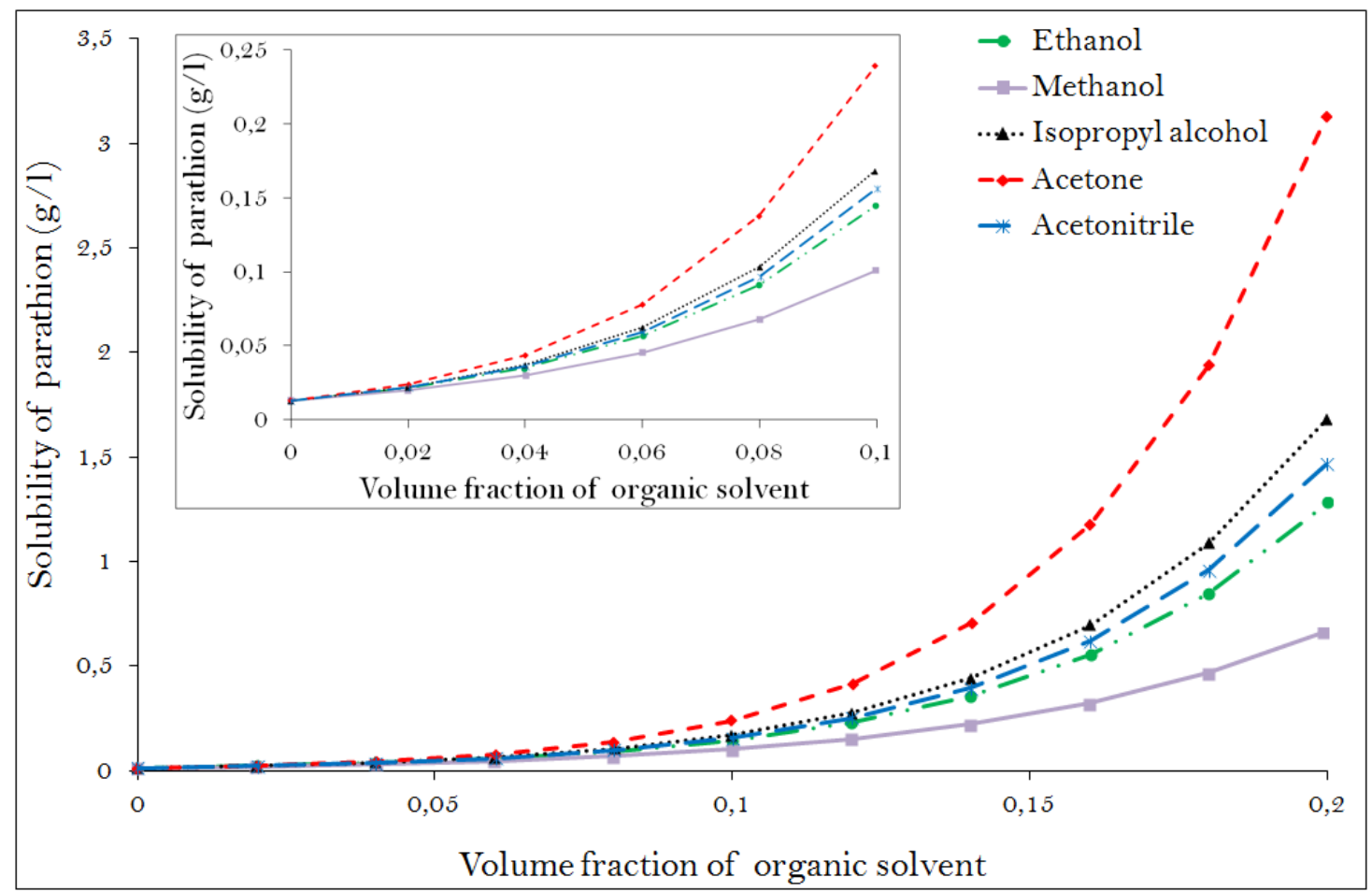

Figure 1. Solubility of parathion in water organic solvent mixtures. 
analysis performedanalysis performed by enzymatic biosensor. However organic solvents have variousphysico-chemical effects on enzyme molecules depending on the nature and concentration of the solvent and the nature of enzyme (Turdean and Turdean 2008). It has been suggested that organic solvents tend to displace the water molecules in the hydration layer and therefore distort the interactions responsible for maintaining the native conformation of the enzyme (Pazhang et al. 2006).It is necessary to choose the organic solvent and its level by taking into consideration both the lowest loss of enzyme activity and highest solubility of pesticide.

\section{Conclusions}

Since most OP possesses only limited water-solubility, water-miscible organic solvents necessarily have to be applied for pesticide analysis. Thus, the applied solvent has to be carefully chosen, by taking into consideration the solubility of OP in selected organic solvent and its influence on enzyme molecule if the residue analysis is performed by enzymatic biosensor. This study reports new theoretical solubility data of parathion as a model OP in five different water organic solvents (ethanol, methanol, isopropyl alcohol, acetone and acetonitrile) mixture.

The thermodynamic solid liquid equilibrium was employed for the solubility calculation. Results in this study demonstrated that acetone is the best solvent for parathion solubility. Another indication is that, the solubility of parathion in pure water at room temperature was found as $12.86 \mathrm{mg} / \mathrm{L}$ which is consistent with the literature data. This resultassures the accuracy of the predictions; therefore, the proposedthermodynamic model can be used to calculate the solubility of parathion and choose the bestsolvent for parathion with respect to solubility amount. This model can also be used to estimate the solubility of other OP in various water organic solvent mixtures.

\section{References}

Walz I., Schwack W., 2007. Cutinase inhibition by means of insecticidal organophosphates and carbamates Part 1: Basics in development of a new enzyme assay.Eur. Food. Res. Technol., 225, 593-601.
Rekha K., Gouda M.D., Thakur M.S., Karanth N.G., 2000. Ascorbate oxidase based amperometric biosensor for organophosphorous pesticide monitoring. Biosensors \& Bioelectronics, 15, 499-502.

Solna R., Sapelnikovab S., Skladal P., Winther-Nielsenc M., Carlssond C., Emneusb J., Ruzgasb T., 2005. Multienzyme electrochemical array sensor for determination of phenols and pesticides.Talanta, 65, 349-357.

Lee H.S., Kim Y.A., Cho Y.A., Lee Y.T., 2002. Oxidation of organophosphorous pesticide for the sensitive detection by cholinesterase-based biosensor. Chemosphere, 46, 571576.

Ramırez G.V., Fournier D., Ramırez-Silva M.T., Marty J.L., 2008. Sensitive amperometric biosensor for dichlorovos quantification: Application to detection of residues on apple skin. Talanta, 74, 741-746.

Turdean G.L., Turdean M.S., 2008. Synergetic effect of organic solvents and paraoxon on the immobilized acetylcholinesterase. Pesticide Biochemistry and Physiology, 90, 73-81.

Pazhang M., Khajeh K., Ranjbar B., Hosseinkhani S., 2006. Effects of water-miscible solvents and polyhydroxy compoundson the structure and enzymatic activity of thermolysin.Journal of Biotechnology, 127, 45-53.

Sandler S.I., 2006. Chemical, Biochemical, and Engineering Thermodynamics, $4^{\text {th }}$ Edition, Jonh Wiley and Sons Inc., USA.

Mackay D., Shiu W.Y., Ma K.C., Lee S.C., 2006. Handbook of Physical-Chemical Properties and Environmental Fate for Organic Chemicals, Second edition, Taylor \& Francis Group, Boca Raton.

Leontarakis G., Tsavas P., Voutsas E., Magoulas K., andTassios D., 2005. Experimental and Predicted Results of Anomeric Equilibrium ofGlucose in Alcohols.J. Chem. Eng. Data,50, 1924-1927.

Spiliotis N., Tassios D., 2000.A UNIFAC model for phase equilibrium calculations inaqueous and nonaqueous sugar solutions. Fluid Phase Equilibria,173, 39-55.

Burke J., 1984. Solubility Parameters: Theory and Application. The Oakland Museum of California 